\title{
DESTINATION: ARANSAS NATIONAL WILDLIFE REFUGE, TEXAS, JANUARY 1993
}

\author{
GILLIAN RICHARDSON, 2450 Crowe Bay, Regina, Saskatchewan. S4V oV7
}

Looking for a winter birding destination, not too far, not too costly? Try southern Texas - not so hot you will suffer meteorological shock going from $-35^{\circ}$ to $+35^{\circ}$, but mild enough for a light sweater or windbreaker, and humid enough to give you a refreshing break from the cold, dry effects of a prairie winter. Added bonus - great birding!

Among other birding spots in the area, Aransas National Wildlife Refuge on the Gulf Coast boasts a possible count of over 350 species during the winter season due to its strategic location directly in the path of the central flyway, and to the variety of habitats on the refuge including salt marsh, grassland and oak woods. Of primary interest to many visitors is the Whooping Crane, as this is the winter destination of the Wood Buffalo flock. Thirty-seven species of mammals also make their homes there.

Comprising almost 55,000 acres, Aransas was established in 1937 to protect vanishing species of the coastal area. Upon approach from the south, via the town of Rockport, it seems an unlikely spot for a refuge. The coast from Corpus Christi north to Galveston area is littered with unsightly oil and gas refineries and petrochemical plants, ship-building facilities, small urban areas and the inevitable road construction. Low, agricultural land makes up the remaining landscape and, before we actually entered the refuge, we sighted meadowlarks and numerous hawks. Large flocks of Snow and Blue Geese feed in the ploughed fields. Both Turkey and Black Vultures take advantage of meals found in roadside ditches. Wherever there are marshy spots Great Blue Herons, Great Egrets and Snowy Egrets hunt.

The morning was foggy, but the mist kept shifting as my husband and I wove our way along the route which borders sections of farmland. After close to an hour's drive from Corpus Christi (with several impromptu stops to raise binoculars in response to "What was that?") we entered a wooded area and approached the refuge entry gate. Hold it - wild turkeys, two of them, foraging alongside the road, almost at arm's length. A good omen, perhaps? It was Christmas season, after all!

First, a visit to the headquarters 
building near the gate. Although there is no entry fee, visitors are requested to sign in. The headquarters has a walk-through display of small dioramas showing various habitats and the wildlife you are likely to see. A good selection of books is available for purchase, and birding lists are provided free. A chart showing current Whooping Crane activity is located just inside the door. For the 1992-93 winter, 135 cranes had arrived at the refuge, out of an expected total of 145 . Fifteen young cranes had completed migration from Canada.

Where could we see the cranes? Hopes diminished when the response was, "There is only one pair visible from within the refuge itself." Others could be sighted from the tour boats out of Rockport (more about that later). The single pair might be in one of two locations, at the end of a hiking trail nearby, or from the observation tower further into the refuge. A setback! After travelling so many miles, with fog threatening to obscure our vision, how would we locate only two white birds in 55,000 acres?

Undaunted, we set off along the Heron Flats Trail which led us from the roadside parking lot into thickets of oak and redbay towards the shoreline. Our first encounter pairs of cardinals in their red finery. Other songbirds and flycatchers eluded identification (we are amateurs yet!) in their unfamiliar winter plumage, but there were many. The path twisted through brush, emerged from time to time along a line of sand dunes and at one point detoured to an observation platform. Geese and waders were visible along the tidal marshes, but no whoopers. The trail eventually flattened out to follow a straight track between permanently water-filled ditches and dunes. There be dragons! American Alligators one of six endangered species sheltered in the refuge - floated like so many logs with bulging eyes. We completed the trail in about 40 minutes, still whooper-less. Only one chance left - the observation tower, and a change in the weather!

Passing a picnic area, our attention was diverted by the sight of a javelina or wild pig scrounging for leftovers. It trotted off, grunting, unwilling to pose for a photograph. Across the road, a short trail led to the water's edge where old pilings were now used as heron perches. Three species in one binocular frame! The Little Blue and Tri-Colored Herons were new for me, a Great Blue made up the trio. Wading close to shore was a Long-billed Curlew. Again the mist closed down, and we moved on in search of whoopers.

The observation tower stands about four stories high. It is wheelchair accessible via sloping ramps. Scopes are set up on the tower for visitors to use. The view from the top was worth the whole trip - tidal marshes, Mustang Lake open at both ends to the bay, and best of all, the elusive Whooping Cranes! The fog had conveniently lifted to reveal a pair feeding in the shallows along with hundreds of ducks, geese and shorebirds.

The Whooping Cranes of Aransas have carefully defended territories along the shoreline. Only this one pair occupied the area within sight of the tower. We watched them feeding, stretching their wings and walking along the edge of the marsh.

It was hard to tear ourselves away. Only two cranes! We had plans to 
take the boat tour, if the weather cooperated, but that was not a certainty. Once down from the tower, the cranes were not visible. We walked a nearby boardwalk trail to check out the birds feeding along the shoreline - more waders, but none to add to our list. The Big Tree Trail was handy and took only a few minutes. The woods were thick, but quiet and we were not even bothered by the mosquitoes we'd been warned to expect.

The rest of the road through the refuge is a driving route. It took us about 45 minutes and produced two completely indifferent armadillos snuffling in the ditch, a coyote heading across country, several more javelinas and a White-tailed Deer. No sign of the Bobcats or Cougars that inhabit the area, although I overheard a visitor at the centre say he'd seen a Bobcat the week before. Hawks and vultures were seen frequently.

The refuge is open during daylight hours. We left in late afternoon to return to our motel in Corpus Christi. Later, we discovered better and more convenient lodging in Rockport which we used the following night, after the boat tour.

The tour boat, Pisces, operated by Captain John Howell, did turn out to be the best way to see Whooping Cranes. The weather cleared for us to take the 4-hour trip (\$18 US each) the next afternoon. Pisces is based in Rockport, a fishing harbour, and travels to the refuge along part of the Intercoastal Canal, a link in the route you could follow from the Great Lakes to South America. It is used by commercial shipping, including the barges loaded with hazardous materials which passed our 58-foot tour boat almost at arm's length.
Whooping Cranes have certainly picked a fragile habitat for their winter quarters.

Our tour guide entertained us during the hour-long ride to the refuge area with information about the ship canal, the history of the local coastal area and interesting facts about the cranes which are a major tourist attraction. We passed sand bars occupied by Double-crested and Oliva- ceous Cormorants. A pair of American Oystercatchers were distant, but visible and new to my list. Several species of gulls and terns wheeled and dived over our wake. Once into the sheltered bay of the refuge, the boat was "grounded" in the sandy shallows and the engine cut so we could enjoy a close up look at the cranes.

They were easily visible without binoculars, but with the glasses it was possible to see the colours of their leg bands. Our guide explained how each pair returned to the same part of the refuge each winter, sometimes with their young. The sub-adult groups moved within these territories until they paired off and attempted to secure an area of their own. We saw several pairs, family groups with a juvenile, and other groups of eight or more sub-adults. Our total count, including the pair seen from the tower, was 28 . We were treated to a brief display of dancing by one pair.

The boat tour also provided us with delicate pink Roseate Spocnbills, a large flock of American Avocets in their smart grey winter garb, and a close look at a Peregrine Falcon resting on a channel marker.

Aransas seems to have a precarious existence. Shielded from the weather off the Gulf of Mexico only by a narrow string of low islands, 
hemmed in by industry with the potential for untold damage from pollution, nevertheless thousands of birds depend on it for a winter base with its rich feeding grounds and mild climate. While the local people consider the birds "theirs," we saw many of "our" familiar species in a fascinating new setting. We envied them the opportunity to stay behind, while we turned our faces north once again to winter. I wonder if that Whooping Crane with the double yellow bands will be the one I eventually get to see somewhere in Saskatchewan?

A list of species we sighted follows:
Common Loon

Pied-billed Grebe

Brown Pelican

White Pelican

Double-crested

Cormorant

Olivaceous Cormorant

Great Blue Heron

Little Blue Heron

Tri-colored Heron

Great Egret

Snowy Egret

Roseate Spoonbill

Canada Goose

Snow (Blue) Goose

Black-bellied Whistling

Duck

Black Duck

Mottled Duck

American Wigeon

Northern Pintail
Northern Shoveler

Ring-necked Duck

Redhead

Red-breasted

Merganser

Turkey Vulture

Black Vulture

Red-tailed Hawk

White-tailed Hawk

Northern Harrier

American Kestrel

Peregrine Falcon

Wild Turkey

Whooping Crane

Sandhill Crane

Common Moorhen

American Oyster-

catcher

Ruddy Turnstone

Long-billed Curlew

Spotted Sandpiper
Willet

Greater Yellowlegs

American Avocet

Bonaparte's Gull

Herring Gull

Laughing Gull

Ring-billed Gull

Forster's Tern

Common Tern

Royal Tern

Mourning Dove

Belted Kingfisher

Brown Thrasher

American Robin

Loggerhead Shrike

Yellow-rumped

Warbler

Eastern (?)

Meadowlark

Boat-tailed Grackle

Northern Cardinal

Ed. note: We encourage others to write about good birding holidays they have had.

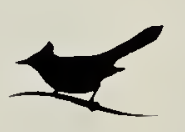

May is the transition month, and exists to connect April and June, the root with the flower. John Burroughs. 1895. Wake Robin. Houghton Mifflin, Boston. 